\title{
Operating Anew: Queering GIS with Good Enough Software
}

\author{
SHORT TITLE: Operating Anew \\ Jen Jack Gieseking \\ American Studies Program, Trinity College
}

In the last decade, conversations around queering of GIScience emerged. Drawing on literature from feminist and queer critical GIS with special attention to the under-examined political economy of GIS, I suggest that the critical project of queering all of GIS, both GIScience and GISystems, requires not just recognition of the labor and lives of queers and research in geographies of sexualities. Based upon a queer feminist political economic critique and evidenced in my teaching critical GIS at two elite liberal arts colleges, I argue that "status quo" between ESRI and geography as a field must be interrupted. Extending a critical GIS focus beyond data structures and data ethics, I argue that geographic researchers and instructors have a responsibility in queering our choice and production of software, algorithms, and code alike. I call this production and choice of democratic, accessible, and useful software by, for, and about the needs of its users good enough software. Instead, I argue that "status quo" between ESRI and geography as a field must be interrupted.

Keywords: critical GIS, queer, QGIS, pedagogy, free and open-sourced software (FOSS)

Key message:

- I argue that "status quo" between ESRI and geography as a field must be interrupted.

- Geographic researchers and instructors have a responsibility in queering our choice and production of software, algorithms, and code alike

- The production and choice of democratic, accessible, and useful software by, for, and about the needs of its users good enough software. 


\section{Operating Anew: Queering GIS with Good Enough Software}

Jen Jack Gieseking

American Studies Program, Trinity College

In the last decade, conversations around queering of GIS have emerged. Queering allows scholars an analytic from which to refuse norms, hierarchies, and binaries in order to accept fluidity, rather than assume the fixity of positions and knowledge. Queering GIS is applicable in a variety of areas, from research to teaching, from other academic labor such as service and advising to the act of selecting and producing our software. Such a participatory position urges GIS users to let go of how we think GIS must work and reinvent the geographical imagination of GIS to create an operating system of our own.

Drawing on literature from feminist and queer critical GIS with special attention to the underexamined political economy of GIS, I argue that "status quo" between ESRI and geography as a field must be interrupted. My arguments derive from my experience of teaching critical GIS at two elite, U.S. New England liberal arts colleges: Trinity College and Bowdoin College. I suggest that the critical project of queering all of GIS, both GIScience and GISystems, requires not just recognition of the labor and lives of queers and research in geographies of sexualities, and participating in these debates. Extending a queer critical GIS focus beyond data structures and data ethics, I argue that geographic researchers and instructors have a responsibility in queering our choice and production of software, algorithms, and code alike. I call this production and choice of democratic, accessible, and useful software by, for, and about the needs of its users good enough software.

My call for the use of good enough software evolves primarily from a queer feminist approach which refuses norms and hierarchies, namely top-down notions of a GIS "industry standard" defined by ESRI products alone. Assumptions of what is the "industry standard" evolve from the literature, conference papers, and marketing alike. For example, in a review of EBSCO's Academic Search Premiere article database in October 2016 mentions of the words GIS and any of the following terms, the variations in software mentions are staggering. Open source desktop applications are mentioned least, such as OpenJUMP (11) 
and QGIS (246); web-based applications rank next, including Vojo.co (2), CartoDB (11), MapBox (22), OSM (286), and Google Maps (749); and proprietary desktop applications take the top position, i.e. ArcView (3,299), ArcGIS (5,722), and ESRI (6,617). Put another way, ESRI alone is mentioned over $60 \%$ more than web-based applications and a staggering $600 \%$ more than open source GIS desktop applications! While these mentions do not definitively define what software is used or taught, they mark powerful trends in the field.

The political economy of these rankings is also important: at-cost of desktop packages are mentioned foremost, followed by less costly geoweb applications, with open source desktop platforms last. ESRI products are surely the most advanced, but they also require expensive licenses. Proprietary products may be less difficult for students to purchase, but are especially costly for recent graduates, the unemployed and partially employed, non-profits, start-ups, small businesses, and community activists. In 2014, a professional license cost $\$ 1,500$ for ArcGIS Basic, \$7,000 for ArcGIS Standard, and costs varied for ArcGIS Advanced. Defining any type software as the "standard" for a field-let alone letting an academic discipline slide merely into the realm of "industry"-and then denying access to that software is an act of injustice. Or, as David O'Sullivan writes in an important footnote, "At the prices ESRI charge for their software, it is hard to see how the technology can empower anyone not already empowered!" (2006, 789).

Most activists, NGOs, students, and even scholars require more basic map design and spatial statistics than at-cost packages entail, while formal training is often necessary for most to make full use of most GIS applocations. Teaching and learning GIS can be difficult for a myriad of reasons, including internet bandwidth, hardware issues, spatial data availability and permissions, competence with learning software generally, and cost of software service (see Kerski 2015; Rickles and Ellul 2015). These various dilemmas mask the most vital issue: the distinction between "training" for GIS "skills" versus critical education of the development and use of GIS data, software, and algorithms (Ghose 2001; Sinha et al. 2016).

Offering students the ability to learn and critically engage with the "industry standard" is important for furthering GIS analysis but, I suggest, the political economic constraints of 
such complicated programs should afford students the ability to learn GIS as a way of thinking and mapping beyond software alone. Like choosing the right method to fit a research question, teachers and researchers must select and/or program software-good enough software-to fit their goals and needs. What is at stake is the field of geography's power in shaping what is possible of GIS rather than assuming ESRI as the "industry standard." It is imperative that critical GIS also invigorate for a choice in our software by geographers, those who teach and research what knowledge defines geography itself. I reflect on teaching the free and open source (FOSS) software QGIS (qgis.org), a GIS software package licensed under the GNU public license, along with other publicly accessible software. I pay special attention to the political economic benefits and drawbacks for transmitting the knowledge of GIS as a case for queering critical GIS.

\section{A Queer Feminist Approach for Critical GIS}

At the turn of the century, fiery debates about the role, use, and limitation of GIS erupted. Many critical geographers highlighted the "implications of GIS and its deleterious effects for society," such as surveillance, military deployment, complicity in capitalist economic growth, masculinist algorithms (Leszczynski 2009, 582). Many of the positive-and sometimes less critical-portrayals of GIS relate to studies and pedagogies of empowerment and social change: participatory GIS (PGIS) or public participation GIS (PPGIS) using both geoweb application or desktop GIS. Scholars have combined P/PGIS with fieldwork to teach activists, community partners, and students alike to address the limits and uses of GIS (see Rickles and Ellul 2015; Sinha et al. 2016). Critical GIS recognizes the limits to GIS as a solution for the common good: "It would certainly be easy to see the range and vitality of PGIS [participatory GIS] work as vindication of naively optimistic approaches that suggest GIS is an infinitely malleable and neutral technology applicable by any community for the furtherance of their own ends" (O'Sullivan 2006, 785). In other words, merely teaching GIS to community members may produce the same maps of injustice that critical GIS studies seek to intervene in. Instead, critical GIS asks us to examine the dimensions of social, economic, and political power and inequality related to and revealed by GIS.

The profound limits and opportunities of GIS relate to and develop from issues of political economy. GIS's standard-bearer as geography's key offering in the public imaginary relates 
heavily to ESRI's monopoly status in the field as GIS software provider, and both GIS and ESRI represent if not define the field to other disciplines and the public. Just two years previous, GIS scholars reflected on the University of Washington's Friday Harbor Laboratories 2014 meeting: "we find that a political economy of geospatial technologies remains largely undeveloped" (Thatcher et al. 2015, 817). This call reasserts Nadine Schurrman's 2002 urging to place social theory and GIS in dialogue so that technology not be seen as "somehow separate from society" $(2002,261)$. Not just a problem in geography, digital humanists write about how the same absence painfully resonates in their own work as well (see Liu 2012; McPherson 2014; Posner 2016). I pick up this under-examined thread of political economy through a queer feminist lens.

While queering has been a more recent addition to critical GIS, feminist approaches marked a sharp turn in the tone of conversations around the politics of GIS. Mei-Po Kwan's (2002b) important article on "feminist visualization" argues for working from situated knowledges against positivistic assumptions and limitations. Such important work continues today. Leszczynski and Elwood (2015) noted how experiences in gender matters in new "practices of data creation and curation"-and the ways in which digital spatialities shape everyday life, from social media to smart phones, the marketing and decreasing privacy of our data to drone surveillance.

The project of queering geography extends feminist approaches by requiring an account of queer identities and engaging in a broader project of refuting norms, binaries, and hierarchies. Work on queering and queer GIS stems from two papers from Brown and Knopp that focus on geospatial data. In "Place or Polygons" (2006), they speak to the insights and misassumptions of The Gay \& Lesbian Atlas (2004) by showing the ways that scale masks the lived experience of lesbian, gay, bisexual, trans, and/or queer (LGBTQ) life as lived neighborhood borders do not sync with census tract borders. Brown and Knopp take a queer turn for critical GIS when they argue that data and scale have "potentially very powerful consequences for the production of visible political subjects...and hence to the processes and practices constituting governmentality" (2006, 236-37). The authors write about this catch-22 for and from a queer epistemology: 
Like all political and decision-making processes, those around participatory GIS are shot through with multidimensional power relations of class, race, and gender, structural forces of capitalism, unequal access to spatial data, and unanticipated and antidemocratic outcomes $(2008,44)$.

Their argument, which calls for queering the map (2008), speaks to the queer tensions in the act of mapping itself: the fixity of categorization, the debatable categories of what counts as a LGBTQ place or not, and the shifting nature of what counts as LGBTQ over time.

Queer theory in other fields, such as communications studies, shares an analysis linking the political economy of software to inequalities. For example, Shaka McGlotten (2016) writes in his queer, critical race work on black data that we are controlled and captured through capitalist derived and supported means of data collection and analysis. If we take up McGlotten, Brown, and Knopp's insights, we find ourselves returning to question the social inequalities written into the algorithms and structure of code of software. This literature heavily shaped my teaching of the open source GIS software QGIS. In the next section, I describe the queerly framed pedagogy of those classes and the outcomes of students learning a program they can use and apply again without financial burdens. ${ }^{1}$

\section{In the Field and at the Monitor: The Digital Image of Two Cities}

I teach and have taught in two elite undergraduate liberal arts colleges, Bowdoin College and Trinity College. In these colleges, like most U.S. colleges (i.e. not research universities), geography by and large remains the work of one full-time lecturer who instructs GIS courses. The course, Digital Image of the City (DIOTC), attempted to further bring critical GIS to both campuses (http://commons.trincoll.edu/amst-digitalcity/). Like Rina Ghose who taught a group of working class urban activists to use GIS, I wanted to give my students knowledge about cartography and GIS in order to "access public information, create new database from their own surveys, and analyzing these databases" and, in so doing, to inform city policy and management $(2001,141)$. Unlike Ghose, the students in my colleges were largely white, middle and upper class, and had access to resources both on campus and beyond. As such, my focus was to have students in a participatory approach, to listen and learn from the 
citizens of the urban communities we studied rather than project their goals and expectations upon them. I describe the course goals, projects, interaction with community partners, process of conducting research, creation of digital data, and the GIS education process itself; I use the identical structure to Ghose's paper in the hopes it can be a model for increasing pedagogical discussion in research conversations.

\section{Course Goals}

In the fall of 2014, I originated DIOTC at Bowdoin College in Brunswick, Maine about Portland, Maine (35 miles south), and I taught the course for a second time in the fall of 2015 at Trinity College in Hartford, Connecticut about Hartford. New England liberal arts colleges of ivy and classical brick architecture with resplendent quads tend to reside in small towns, with Trinity being the only exception to reside in a city. Both New England cities (i.e. northeastern U.S. cities) would be considered smaller cities, with populations of 66,000 in Portland and 514,000 in the metropolitan area, and 120,000 in Hartford and 1.2 million in the metropolitan area (see Chen and Bacon 2013). Portland thrives, like the State of Maine, on its primary industry of tourism, while Hartford is one of the poorest U.S. cities in one of the richest states and has not recovered from the overseas export of most industrial employment. While projects about the city are common at Trinity which supports a worldrenowned Community Learning Initiative, my Bowdoin course was the first in the college's 221 year history to focus on the nearby city of Portland.

DIOTC was originated in Bowdoin's emerging Digital and Computational Studies program, which drew students across the disciplines, and then reworked the course for Trinity's American Studies program, which drew primarily humanities-based studies before my arrival. The core-learning goal for both courses was identical: "Through in class discussions and research and writing assignments, you will develop fluency in cutting-edge issues around urban issues and hone your own position on these debates." I blended urban theory, urban studies, and critical GIS and cartography readings on the city of study, New York City (as a nearby, relatable, and popular example), and national and international trends to allow students a lens through which to read and act within the complexity of the city. Students alternated among reading discussion classes, field trips, social science data gathering lessons and exercises, and QGIS lessons, each class relating to the last and next. Our 
readings on the power of maps and the critical history of their production shocked my students on both campuses. We talked at length about the power to shape the way we imagine and experience the world as digital cartographers using GIS, and the responsibility that goes with that. One-third of course time was devoted to learning GIS, how to find and make use of open data, how to create datasets relevant to their projects, and how to understand the process of research in each of our steps.

The multi-layered project requirements and readings were a tall order but each element was required to piece together a deep understanding of the city. Both classes sought to help develop the student's ability to speak and even intervene on issues of social and spatial injustice in partnership with government officials and citizen-activists. Few of the students had walked either city, and only some had visited these cities beyond entering a café, bar, concert, or museum. Pushing them to think about and account for their positions of privilege in their relationship to the city and their residents was essential. I asked them to think through and articulate their own ideas of the "common good" for cities to help illuminate who they worked for and with, and to what ends.

\section{Project and Process: Comprehending and Mapping City Needs}

As a pedagogue who believes in teaching the practice of research in the classroom, I begin each of my classes with the first two pages of postcolonial scholar Arjun Appadurai's "Right to Research." Appadurai argues that the "right to research" is a "specialized name for a generalized capacity to make interdisciplinary inquiries into those things we need to know, but do not know yet" $(2006,167)$. Appadurai calls for the $30 \%$ of the world's population with no access to higher education to lay claim to the right to research. I use his powerful statement as a way to get my students at elite institutions to take up their role in researching with those who have less power. We discussed how democratic, critical geography and GIS indeed is more than a matter of access (see Haklay 2013; Aalbers 2014). Critical GIS grew as an idea to them as we critically examined and made maps, and thought through the software, data, and structures that shape everyday understanding of space, self, and other. 
Students' final projects required them to choose an issue identified by the city's citizens, key stakeholders, and/or media. In that way, they work for and with rather than merely about an issue. I see this interaction as a queer feminist intervention in traditional, top-down city planning processes that afforded bottom-up contributions from youth and the people they interviewed and interacted with. Using qualitative and GIS research, students were to describe the look and function (but not actually code) of a website, app, or technological infrastructure that could improve the city for the common good. I was intent on teaching students GIS through a lens of public and self-empowerment, to give them the tools to shape the world they see for, by, and about the common good. Drawing on their wide range and use of digital platforms and devices as college-aged students (all were traditional college age), the students possessed technological imaginations that gave way for apps, sites, and infrastructure that exceeded traditional urban planning. To that end, I combined problem-based learning about real world issues in both cities with field work and critical GIS in the form of student research projects (see Ellul 2015; Sinha et al. 2016).

With 24 students in my Bowdoin class and 8 in my Trinity seminar, about one-fourth of my Bowdoin students had taken a GIS class and none of my Trinity students had done so. The former worked in three groups focused on issues of housing, public space, and infrastructure, while the latter could select any of these issues to study individually. Their research project description read as follows:

You will learn the process of social science research by collecting your own data about the city in multiple data collection trips in Portland/Hartford, and then making, procuring, and analyzing datasets relevant to your research topic via GIS. This project will allow you to develop your verbal, spatial, and critical thinking skills by reviewing city issues through the lens of your qualitative and quantitative data, as well as through core and cutting-edge readings on urbanization and smart cities. You will develop a robust understanding of how data visualizations and analysis can support the future of urbanism for the common good.

Through class discussions, I had the students push back against and complicate one another's conceptualizations of the "common good" to reach a critical positionality. The students found this stressful at times in confronting their own privilege and embarrassing at 
times. Still, they learned how their ideas of how society worked and their geographical imagination of those power dynamics rested on stereotypes (racist or classist, gender or sexual), but also remarked that this work was exciting, eye-opening, and important.

\section{Interaction with Citizen-Activists and Government Officials}

In teaching GIS to community activists, Ghose sought to follow "the principle that effective access to information leads to better government as well as to community empowerment" (2001, 141). In step with this approach, both groups attended historical tours of the cities that I led and spoke to and toured the city with key leaders in the city government and citizen-activists. Bowdoin students met Portland city officials including the GIS experts for the city and the city's urban designer. Trinity students took an afternoon-long tour of the Asylum Hill neighborhood in Hartford led by a citizen-activist and civil servant. This exposure to city leaders was cited often by students as they felt certain the work they were doing meant something to the people they spoke to. Students were thrilled to work on "real world" issues and, by working directly with and for community partners and citizens on issues they faced. They felt they could contribute in a small way through their knowledge and passion about digital platforms in their design, which both cities lacked the time, resources, and skills to research. At the same time, the students were forced to confront, shift, and even queer their false assumptions about cities, the people within them, and power dynamics between them.

\section{Conducting Research in the City}

Students at both colleges conducted parallel data collection assignments: both groups were tasked with spending significant time on their own in the city, walking the city, and speaking to residents to gather mental maps from them and ideas about what could benefit the city around their central issue. We read about and then practiced each method in class-for example, collecting mental maps from other students of their campuses-before applying that method in the field. Here, I took up a queer feminist politic to have students gain their own situated knowledges about the city and its political economy, rather than act as outside actors with the "God's eye view" of GIS (see Kwan 2002b). 
Bowdoin students also conducted café mini-ethnographies and transect walks of various Portland neighborhoods, while Trinity students spent more time in Hartford on-site visits with community activists. By varying students' exposure both to city leaders and its supposedly anonymous citizenry, students had to grapple with creating projects and data that addressed and promoted the common good, while reckoning with the meaning of the "common good" in their projects. Students also learned about and took part in IRB certification.

\section{Creation of Digital Data by Students}

Both semesters of the DIOTC course relied on reaching out to key contacts on campus, using open datasets, and teaching students to create their own datasets (see Acknowledgments). My students and I found we faced a similar issues as Marianna Pavlovskaya (2006) in her use of Moscow public data: much public data obscured the scales of intimate everyday life the students' projects sough to address. Like Pavlovskaya, we took up the feminist intervention to produce her own data to fill in scales yet unrecorded, such as the aftermath of public shootings, local food access, and the experience of public housing. Students were also assigned the text of gathering and mapping a dataset of 20 to 40 points related to their project. Queering expectations of what counts as data helped students to develop a feminist, critical understanding of GIS as a whole. Learning GIS, as noted below, gave them a great sense of self-worth and new understandings about their relationship to space and place, both groups of students expressed shock and awe that they had the power to produce and map their own data.

Bringing back the students' new geographical imaginations to our in-class readings, Stephen Graham's (2005) work on software-sorted geographies shows how we are not just read but sorted into spaces by code. The sociopolitical milieu in which we encode software, file structures, and define the shape of data also reproduces the inequalities. Queer theory works against such "normal" categories or infrastructures, almost always binaries, that simplify human complexity. When we read Graham in class, students quickly connected his arguments to the assumptions we categorized data, and used colors and classifications to label data-all of which could obscure the "ground truth" of everyday life. 


\section{The GIS Education Process}

Every third class of our 13 class meetings was devoted to learning the QGIS package to map of existent and new datasets, as well as basic spatial statistical analysis. The central software I chose to teach in both classes was QGIS, an open source GIS platform that works on Windows, Apple, and LINUX machines so that students could use the software free of cost while students and after graduation. I introduced students to open source debates and we reviewed other possible software as I explained my use of QGIS regarding their ability to use it, free of cost, into the future, including a brief tour of ESRI's ArcGIS Basic package, to which both colleges possess licenses. I reiterated often that once they knew QGIS, students had the ability to apply their QGIS understanding to ESRI and other GIS software with selftraining using blogs or videos should they choose. Students admitted freely that they liked "rooting for the underdog" by working with less used, open source software-and relief they could afford to continue such research and work after graduation. A queer feminist intervention that we shared as a group was their excitement regarding the applicability of their GIS skills after college regardless of software package. This became apparent when we did an ArcGIS walkthrough and students saw the similarity of the buttons, menus, and functionality.

Many scholars have remarked to me that they found my choice of QGIS in the classroom to be a bold one. Other GIS teachers report that the limited instructional literature on QGIS leads them to return to ESRI products, which speaks to the issue that GIS "as an elitist, antidemocratic technology by virtue of its technological complexity" (Ghose 2001, 141). Open source software is also notorious for issues with usability since "developers are not typical end-users" (Nichols and Twidale 2003, 1). Queer feminist interventions into the political economy of GIS require thinking and acting outside of traditional means and software-and they are also collaborative projects. For some years, GIS librarian Frank Donnelly has personally created a set of complete QGIS lessons that cover the basics of mapmaking, which he shares under a Creative Commons license. ${ }^{2}$ I found that the lessons, written for a Windows machine, were easily edited for Apple users. Donnelly includes detailed and clear lessons to find the best place to put a new coffee shop in New York City that is close to a subway stop in a census tract with more women than men (women evidently drink more 
coffee), but not close to another coffee shop. I walked a few students through the process of applying these lessons to their own data while most made the connections with ease.

It took nine hours to teach these lessons to most students who chose a digital studies course at Bowdoin, and about 11 hours to students; both courses ran just under 40 hours total over 13 weeks so that QGIS occupied around one-quarter of our class time. While the more humanities-focused students at Trinity often expressed more frustration with the program, they had less background learning technology in other classes compared to the Bowdoin students. All students expressed a deep sense of excitement when the lessons were complete because they could see the sum of their efforts in answering a real world problem in a formal map.

\section{Findings for, by, and about the Community}

All students were required to use QGIS for their final projects, and I worked with students to help them think through how to take the issue they identified in each city and turn it into mappable points. Most students easily found a public dataset and created their own data, while a few in each class struggled with how to find or make convincing data. Only a small number of students in each class had issues in applying what they had learned in QGIS to their own issue, and I would sit with each of those students to re-read Donnelly's lessons to help them puzzle through how to apply their question to the skills available. Once the connection was made though, the students easily finished the projects on their own, mimicking Donnelly's lessons and then drawing comparisons to the ways other projects could be investigated. 


\section{Making the Internet Accessible}

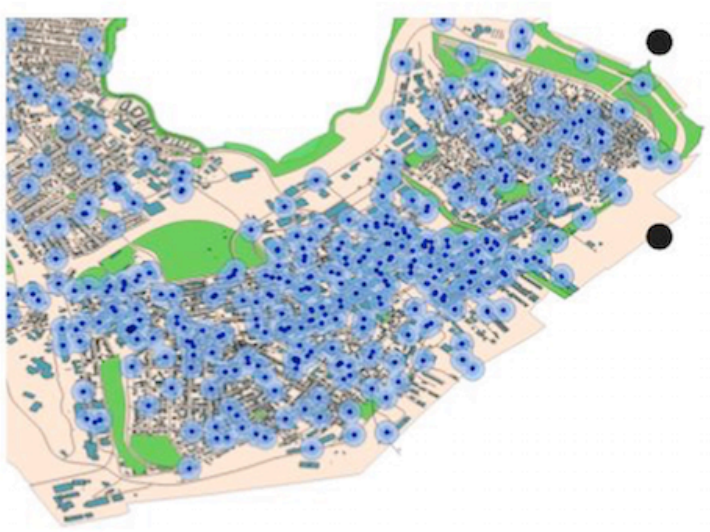

No public Wi-Fi

- Call boxes can be made into hotspots

Many people don't have Internet access

- Computer-sharing program in resource centres

Map data - City of Portland (2014); statistics from city-data.com (2011), time.com (2013)

Figure 1. Bowdoin College student Mingo Sanchez's map of possible public wifi coverage using call boxes in Portland, Maine. 2014.

SOURCES: Map-City of Portland (2014); American Community Survey of the U.S. Census (2013).

Creating a Technology Infrastructure in Hartford

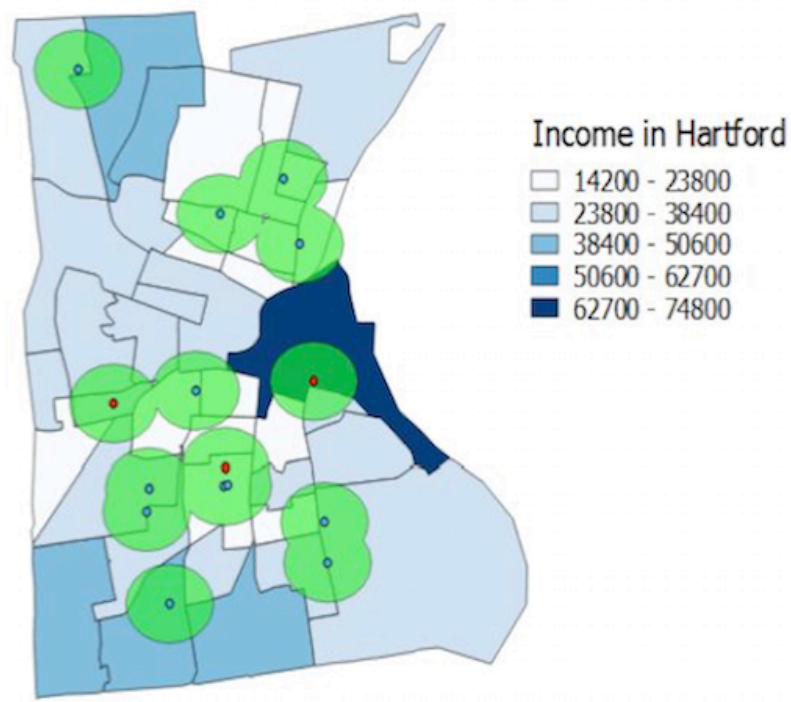

Figure 2. Trinity College student Andrew Fishman's map of the spaces between walkable after school care in Hartford, Connecticut. 2015.

SOURCES: Map-City of Hartford (2015); University of Connecticut Libraries' MAGIC (Map and Geographic Information Center) (2015); American Community Survey of the U.S. Census (2014). 
Students put their ideas into paper and produced public presentations of their work, which I evaluated through the lens of the depths of their reflexivity in their maps, quality of their writing and research, addressing the city's needs, and their applications of the readings in conversation with a robust understanding of the "common good" (see Kwan 2002a). As a result, one student was able to map how predominantly poor people of color would be left out of Portland's plan to run free public wifi through their historic call boxes (see Figure 1), while another student mapped the areas lacking after school care programs that were ripe for new programming (see Figure 2). Whatever was assumed to be hierarchal and fixed became more fluid and responsive to the stories of the citizens of each city in this queer feminist pedagogy.

Portland GIS experts and the city's urban designer and Hartford community activists and other community learning-focused faculty were invited to students' presentations at the end of the semester. At both colleges, students presented well researched ideas tied to existant and new data. The ideas, many of which seemed simple or even obvious, often sought low cost solutions to already existing issues and stretched city budgets. The students' suggestions also sought to increase accessibility to city resources such as bike paths, community supported agriculture, after school care, or buses. These foci reveal the students' notion of the "common good" as improving public city services and resources to benefit as many people as possible.

Those attending student presentations found the research to be insightful and the GIS maps compelling. Donnelly's lessons allow the user to map points and see who they represent and then who they leave out in the spaces between them. The ability to find, choose, and create data while also choosing and making use of GIS excited and invigorated my students, and gave them a great sense of self-empowerment while contributing to nearby urban communities.

\section{Queer Next Steps for Critical GIS}

Recent critical GIS literature produced a flurry of important responses to the big data hype that has dominated digital and computational studies conversations across the disciplines. An exciting and invigorating array of literature on big data discussion in geography is growing 
(Dalton and Thatcher 2014; Kitchin 2014; Burns 2015; Leszczynski 2015; Thatcher et al. 2015; Wilson 2015; Dalton, Taylor, and Thatcher 2016; Gieseking 2017). Queer feminist theory can take these ideas a step further. We must reimagine and operate anew: not only through the production of file structures and data of GIScience alone, but also through the software of GISystems that support and develop from the critical projects of justice we seek to produce. We can see this bridging already in Agnieszka Leszczynski and Sarah Elwood's feminist focus on "new spatial media rather than the geoweb's content forms and data curation practices" such as the API code for gathering social media geodata and the geographies of social media itself $(2015,545)$. Critical GIS still needs to reckon with what Nadine Schuurman refers to as the "loosely defined set of practices" within GIS, whether positive or negative, to determine our power in shaping the world's geographical imaginations.

Projects of queering GIS already abound, and need to be recognized as such. Luke Bergmann describes the speculative data of geographic information-that which can "be reimagined to constitute spaces as relational, matter as vibrant, and/or knowledge as situated" (2016, 1). Bergmann draws on digital humanist Johanna Drucker's (2012) notion of speculative computing whereby scholars "identify core theoretical issues in the humanities and develop digital platforms that arise from these principles," rather create software and make the production of knowledge fit that platform. To speculate is to be engaged in, to express, to be based on conjecture rather than knowledge.

I extend Bergmann's relational-vibrant-situated critique to the project of queering GIS through the choice and production of GIS code and software. To speculate also involves the possibility of loss and risk. Queer life and queer theory develop from an era of loss-the HIV/AIDS crisis wiped out an entire generation of LGBTQ people. Loss and risk are central features of LGBTQ lives and spaces today, such as in the absences, mislabelings, assumptions, and misunderstandings of gathering and mapping this group's history (see Brown and Knopp 2008). The act of queering, then, embraces life as a state of constant risk and possibility. In step with this realization, a queer GIS leaves room in code and software to speculate and collaborate, for the public to fill in the gaps our data always leaves us with. 
Do not cite, quote, or reprint without permission. Instead, cite:

Gieseking, Jen Jack. 2018. Operating Anew: Queering GIS with Good Enough Software. Canadian Geographer.

Queering the corporatization-and simultaenous militarization-of code and on behalf of speculation in our research and teaching, leads me back to my argument for good enough software. The notion of "good enough" comes from psychoanalyst Donald W. Winnicott's (2005) notion of the good enough mother, now the good enough parent. Winnicott railed against prevailing theories of the mid-20th century that painted a "good or bad mother" who met or failed to meet her baby's needs. He instead argued on behalf on competent or "good enough" parenting that met enough of the child's needs that they survive and thrive, while recognizing the faults of humanity within us all. Such a perspective of "enough-ness" is fully queer in its refusal of binary norms.

When extending the frame of enough-ness to code, we arrive at good enough software. My call to critically rethink our software choice, development, and deployment does not mean anything as simplistic as instantly replacing ESRI's ArcView or ArcGIS with the open source QGIS platform. However, I am arguing that geographers begin to define the "standard" of the field as that software that bests fits the research question and data, which is good enough for the issue as hand. On behalf of justice, democratization, and social change, it is up to geographers to teach or use GIS that is good enough software to fit the course or research before them rather than succumb to any corporate branding as an "industry standard." Further, queering GIS urges geographers to create and code new software to meet this agenda. The use of good enough software is not limited to geography or even the social sciences, but must be taken up unilaterally across the disciplines.

In fact, GIScience focuses on "the promise of the future," its technologies define "what is possible to achieve in any given moment"-and therefore fix our imaginations and science in their seemingly set code (Haklay 2012, 478, 477). Brown and Knopp recalled Audre Lorde's key feminist intervention that "the masters' tools cannot dismantle the master's house" when writing on queer GIS: "Geographers have chronicled the ways that marginalized groups have used 'the master's tools' toward their own ends" $(2008,44)$. Yet how could we move beyond the masters' tools and make our own? Why not transform the material relations rather than submit to them (see Koopman 2008)? One queer way forward is to refuse the use of proprietary software in the field or, at a minimum, alternate and balance its use with proprietary software. Eventually, there would no longer be ArcGIS, ArcView, or other ESRI 
packages that cost money or any other partially open or at-cost source software. This is a real queering here: an upset, an undoing, a spike against the flattening of pretend normalcy. Software like OSM, QGIS, OpenJUMP, and vojo.co rip up the assumed "normalization" and "standard" of ArcGIS by affording new tools and software than what is extant, forever affordable and accessible to those we teach, study, and work alongside.

What open world do we perpetuate when operating and teaching in a closed (geographic information) system? Schuurman wrote, "GIS has been somewhat homogenized" as positivistic tools of imperial rule rather than "regarded as a single entity rather than a loosely defined set of practices" (2000, 586; see also Sui 1994). Society begs for increasing means to support analysis for-and visions of-social justice, and projects of participatory GIS proliferate. Critical GIS makes great investigation of GIS's relationship and role in producing new digital software and data, and intervening in the corporate and governmental production and withholding of big data. Communications studies and digital humanities scholar Tara McPherson argues that "we should design our tools differently, in a mode that explicitly engages power and difference from the get-go, laying bare our theoretical allegiances and exploring the intra-actions of culture and matter" $(2014,182)$. As critical GIS scholars have written, counter-data can develop from the work of PPGIS and PGIS initiatives (Dalton and Thatcher 2014; Dalton, Taylor, and Thatcher 2016). I add that for such counter-geodata be truly accessible to all also requires software affordable to all, i.e. free or open source GISystems.

To intervene in and queer our own geographic operating system would be finally end the litany of feminist, participatory, collaborative, queer, political economy, and so on in our description of critical GIS, and bring it to life by laying claim to our own "standard" not define by capitalist goals or corporate industry. The truly queer project of a new "standard" GIS software would, like media scholar Kara Keeling's imagined QueerOS (operating system), make "perceptible presently uncommon senses in the interest of producing a/new commons and/or of proliferating the senses of a commons already in the making" (2009, 53; see also Barnett et al. 2016). To create an operating system of our own would (begin to) dismantle the master's house by making our own tools, in so far as this is possible under the racism, heteropatriarchy, colonialism, and ableism that shapes code itself as well. 


\section{Acknowledgements}

Working with Eileen Johnson at Bowdoin, I was able to obtain complete public datasets from City of Portland data for the college's use. Trinity education professor Jack Dougherty led me to the UCONN Map and Geographic Information Center library that contains vast amounts of state and city data. Along with Eileen and Jack, I express my sincere appreciation to Crystal Hall at Bowdoin College and Caitlin Cameron from the City of Portland, and Cheryl Cape, Carol Clark, and Carlos Espinosa at Trinity College and Jennifer Cassidy from the Asylum Hill Neighborhood Association for their contributions to these courses. My work in Hartford is possible thanks to a Community Learning Initiative grant from Trinity College. My deepest gratitude goes to my students in both classes who went on this wild adventure with me and Frank Donnelly and the people who coded QGIS who made our adventures possible. Finally, I am deeply grateful to Karisa Butler-Wall, as well as the anonymous reviewers and special editors of this issue for their insightful comments.

\section{Works Cited}

Aalbers, Manuel B. 2014. "Do Maps Make Geography? Part 1: Redlining, Planned Shrinkage, and the Places of Decline." ACME: An International E-Journal for Critical Geographies 13 (4): 525-56.

Appadurai, Arjun. 2006. "The Right to Research." Globalisation, Societies and Education 4 (2): $167-77$.

Barnett, Fiona, Zach Blas, Micha Cardénas, Jacob Gaboury, Jessica Marie Johnson, and Margaret Rhee. 2016. “QueerOS: A User's Manual.” In Debates in the Digital Humanities 2016, edited by Matthew K. Gold and Lauren F. Klein. Minneapolis, MN: University Of Minnesota Press. http://dhdebates.gc.cuny.edu/debates/text/56.

Bergmann, Luke. 2016. “Toward Speculative Cata: 'Geographic Information' for Situated Knowledges, Vibrant Matter, and Relational Spaces." Environment and Planning D: Society and Space, August, 1-19.

Brown, Michael, and Lawrence Knopp. 2006. "Places or Polygons? Governmentality, Scale, and the Census in the Gay and Lesbian Atlas." Population, Space and Place 12 (4): 223-42.

—. 2008. "Queering the Map: The Productive Tensions of Colliding Epistemologies." Annals of the Association of American Geographers 98 (1): 40-58.

Burns, Ryan. 2015. "Rethinking Big Data in Digital Humanitarianism: Practices, Epistemologies, and Social Relations." GeoJournal 80 (4): 477-90.

Chen, Xiangming, and Nick Bacon, eds. 2013. Confronting Urban Legacy: Rediscovering Hartford and New England's Forgotten Cities. Lanham, MD: Lexington Books.

Dalton, Craig M., Linnet Taylor, and Jim Thatcher. 2016. "Critical Data Studies: A Dialog on Data and Space." SSRN. 
Dalton, Craig M., and Jim Thatcher. 2014. "Commentary: What Does a Critical Data Studies Look Like, and Why Do We Care? Seven Points for a Critical Approach to 'Big Data.” Environment \& Planning D: Society \& Space, May. http://societyandspace.com/material/commentaries/craig-dalton-and-jim-thatcherwhat-does-a-critical-data-studies-look-like-and-why-do-we-care-seven-points-for-acritical-approach-to-big-data/.

Donnelly, Frank. 2013. "Introduction to GIS Using Open Source Software." Software manual. Baruch College, New York, NY. http://www.baruch.cuny.edu/geoportal/practicum/.

Drucker, Johanna. 2012. "Humanistic Theory and Digital Scholarship." In Debates in the Digital Humanities, edited by Matthew K. Gold. Minneapolis: University Of Minnesota Press.

Ellul, Claire. 2015. "Geography and Geographical Information Science: Interdisciplinary Integrators." Journal of Geography in Higher Education 39 (2): 191-94.

Gates, Gary, Jason Ost, and Elizabeth Birch. 2004. The Gay \& Lesbian Atlas. Washington, D.C: Urban Institute Press.

Ghose, Rhina. 2001. “Use of Information Technology for Community Empowerment: Transforming Geographic Information Systems into Community Information Systems." Transactions in GIS 5 (2).

Gieseking, Jen Jack. 2017. "Size Matters to Lesbians Too: Queer Feminist Interventions into the Scale of Big Data." Professional Geographer.

Graham, Stephen D.N. 2005. "Software-Sorted Geographies." Progress in Human Geography 29 (5): 562-80.

Haklay, Mordechai. 2012. "Geographic Information Science: Tribe, Badge and SubDiscipline." Transactions of the Institute of British Geographers 37 (4): 477-81.

—. 2013. "Neogeography and the Delusion of Democratisation." Environment and Planning A 45 (1): 55-69.

Keeling, Kara. 2009. "Looking for M-: Queer Temporality, Black Political Possibility, and Poetry from the Future." GLQ: A Journal of Lesbian and Gay Studies 15 (4): 565-82.

Kerski, Joseph J. 2015. "Opportunities and Challenges in Using Geospatial Technologies for Education." In Geospatial Technologies and Geography Education in a Changing World: Geospatial Practices and Lessons Learned, edited by Osvaldo Muñiz Solari, Ali Demirci, and J. A. van der Schee, 2015th ed., 183-94. New York, NY: Springer.

Kitchin, Rob. 2014. The Data Revolution: Big Data, Open Data, Data Infrastructures and Their Consequences. Thousand Oaks, CA: Sage.

Koopman, Sara. 2008. "Imperialism Within: Can the Master's Tools Bring Down Empire?" ACME: An International E-Journal for Critical Geographies 7 (2): 283-307.

Kwan, Mei-Po. 2002a. "Is GIS for Women? Reflections on the Critical Discourse in the 1990s." Gender, Place \& Culture 9 (3): 271-79.

—. 2002b. "Feminist Visualization: Re-Envisioning GIS as a Method in Feminist Geographic Research." Annals of the Association of American Geographers 92 (4): 645-61.

Leszczynski, Agnieszka. 2009. "Quantitative Limits to Qualitative Engagements: GIS, Its Critics, and the Philosophical Divide*." The Professional Geographer 61 (3): 350365.

—. 2015. "Spatial Big Data and Anxieties of Control." Environment \& Planning D: Society \& Space 33 (6): 965-84. 
Do not cite, quote, or reprint without permission. Instead, cite:

Gieseking, Jen Jack. 2018. Operating Anew: Queering GIS with Good Enough Software. Canadian Geographer.

Leszczynski, Agnieszka, and Sarah Elwood. 2015. "Feminist Geographies of New Spatial Media." The Canadian Geographer / Le Géographe Canadien 59 (1): 12-28.

Liu, Alan. 2012. "Where Is the Cultural Criticism in the Digital Humanities?" In Debates in the Digital Humanities, edited by Matthew K. Gold, 490-509. Minneapolis: University of Minnesota Press.

McGlotten, Shaka. 2016. “Black Data." In No Tea, No Shade: New Queer of Color Critique, edited by E. Patrick Johnson, 262-86. Durham, NC: Duke University Press.

McPherson, Tara. 2014. “Designing for Difference.” Differences 25 (1): 177-88.

Nichols, David, and Michael Twidale. 2003. "The Usability of Open Source Software." First Monday 8 (1). http://firstmonday.org/ojs/index.php/fm/article/view/1018.

O'Sullivan, David. 2006. “Geographical Information Science: Critical GIS." Progress in Human Geography 30 (6): 783-91.

Pavlovskaya, Marianna. 2006. "Theorizing with GIS: A Tool for Critical Geographies?" Environment \& Planning A 38 (11): 2003-20.

Posner, Miriam. 2016. “Money and Time.” Miriam Posner's Blog. March 14. http://miriamposner.com/blog/money-and-time/.

Rickles, Patrick, and Claire Ellul. 2015. "A Preliminary Investigation into the Challenges of Learning GIS in Interdisciplinary Research." Journal of Geography in Higher Education 39 (2): 226-36.

Schuurman, Nadine. 2000. "Trouble in the Heartland: GIS and Its Critics in the 1990s." Progress in Human Geography 24 (4): 569-90.

—. 2002. "Women and Technology in Geography: A Cyborg Manifesto for GIS." Canadian Geographer / Le Géographe Canadien 46 (3): 258-65.

Sinha, Gaurav, Thomas A. Smucker, Eric J. Lovell, Kgosietsile Velempini, Samuel A. Miller, Daniel Weiner, and Elizabeth Edna Wangui. 2016. "The Pedagogical Benefits of Participatory GIS for Geographic Education.” Journal of Geography 0 (0): 1-15.

Sui, Daniel Z. 1994. "GIS and Urban Studies: Positivism, Post-Positivism, and Beyond." Urban Geography 15 (3): 258-78.

Thatcher, Jim, Luke Bergmann, Britta Ricker, Reuben Rose-Redwood, David O'Sullivan, Trevor J. Barnes, Luke R. Barnesmoore, et al. 2015. "Revisiting Critical GIS." Environment and Planning A, December. http://epn.sagepub.com.ezproxy.trincoll.edu/content/early/2015/12/18/0308518 X15622208.

Wilson, Matthew W. 2015. "New Lines? Enacting a Social History of GIS." The Canadian Geographer / Le Géographe Canadien 59 (1): 29-34.

Winnicott, Donald W. 2005. Playing and Reality. New York: Routledge.

\section{ENDNOTES}

\footnotetext{
${ }^{1}$ The other geoweb software I included in their lessons is beyond the scope of this paper. In brief, I outline our work with Social Explorer, CartoDB, and Google Maps below. Social Explorer afforded a way for users to explore all U.S. census data from 1790 to the present in map form, as the college owns a license to the database; otherwise only the most recent census data is available. The Geo-GoogleDocs plugin geocoded data and export in GEOJSON format in order to work with online geocoding software should they need to in the future. Finally, CartoDB, a webbased application that allows a certain number of maps and datasets under a certain size to be analyzed freely. At the time, QGIS's plugin qgis2leaf to export data to the web does not allow for an embeddable map like CartoDB.
} 
Do not cite, quote, or reprint without permission. Instead, cite:

Gieseking, Jen Jack. 2018. Operating Anew: Queering GIS with Good Enough Software. Canadian Geographer.

${ }^{2}$ Donnelly's (2013) lessons and datasets for those lessons can be found at the following link: https://www.baruch.cuny.edu/confluence/display/geoportal/GIS+Practicum. 